\title{
Language teaching supported by argumentation and authorship
}

\section{Soraya Maria Romano Pacífico}

Docente da Universidade de São Paulo (USP), Brasil

smrpacifico@ffclrp.usp.br

\begin{abstract}
This work aims to analyze argumentation and authorship within texts written by students of elementary school following from the reading and debate of the book of children's literature published by Ruth Rocha. This book was chosen due to the comic's effect that circulates in it since we had the hypothesis that laughter in the literature can facilitate the assumption of authorship and the practice of argumentation in the school context. Considering the evidence marked in the language, the results show that the comic' effect mobilized the production of meanings, and the subjects-students occupied the discursive position of author and practiced the argumentation. We observed that the texts produced by the subjectsstudents are interpretable (i.e., they are not copies of the literary text read), and, above all, there is argumentation on the way in which book's characters "use" the language and how this "use" produces comic effects.
\end{abstract}

Keywords: Discouse. Argumentation. Authorship. Children's literature.

Resumo: Este trabalho visa a analisar a argumentação e a autoria em textos escritos por sujeitos-alunos do Ensino Fundamental a partir da leitura e debate do livro de literatura infantil Uma história com mil macacos, de Ruth Rocha. A escolha do livro deve-se ao efeito cômico que nele circula, visto que tínhamos a hipótese de que o riso na literatura pode facilitar a assunção da autoria e a prática da argumentação no contexto escolar. Considerando os indícios marcados na língua, os resultados mostram que o efeito cômico mobilizou a produção de sentidos, os sujeitos-alunos ocuparam a posição discursiva de autor e praticaram a argumentação. Vimos que os textos produzidos pelos sujeitos-estudantes são interpretáveis, não são cópias do texto literário lido, e, principalmente, há argumentação sobre o modo como os personagens do livro "usam" a língua e como esse "uso" produz efeitos cômicos.

Palavras-chave: Discurso. Argumentação. Autoria. Literatura Infantil. 


\section{Introduction}

$21^{\text {st }}$ Century. The contemporary subject has the illusion that everything can be said, mainly when he is in front of a computer screen that connects him to an illusory, globalized world. To a world supposedly without borders to say, to visit, to make friends, to express opinions, to argue, and, finally, by means of his discourses, as a subject in the world, in the language, having also, the possibility of saying without showing or occulting himself by creating fake profile in social networks to be able to say without being seen or recognized. In any case, it seems to me the contemporary subject has identified himself with the digital environment to constitute himself as a subject who reads and writes, even though he does not' really know who constitutes his target audience.

Although this is the case, an issue always worries me: I wonder if even in these conditions of production, in which there is no school control, no collections of notes, nor the need to perform the homework, the subjects, which I will name here as multimedia-subjects, really, argument and take responsibility for the meanings that put in discourse. Is authorship restricted to typing and posting texts online without the support of an editor or someone who fulfills this function? How does argumentation work, or not, in this process of summoning everything to say?

It is justified in this introduction not to direct the reader to a research on social media writing, but rather to insert the reader in this study that I will be presenting, related to the school context. This is because, if in the social medias the subject does not use the supposed freedom to say everything he or she wants, how will the subject produce meanings in the school context, submitted to the watch and control of the teacher and the textbook? This work was constructed in these conditions of discursive productions. I intend to analyze, here, how the relation of the subject with argumentation and authorship is constructed at school, and what conditions the textbook provides students, so they can feel free and authorized, in and out of school, in a world that claims it in the online and offline environments, all the time.

Bauman, in the book Globalization: Human Consequences analyzes the effects of globalization and, in dealing with the way postmodern society instills in the subject the desire to consume, he writes: 
Everyone can be launched in the fashion of consumption; everyone may wish to be a consumer and take advantage of the opportunities that this way of life offers. But not everyone can be a consumer. Wishing is not enough; to make the desire really desirable and thus to extract pleasure from desire, one must have a rational hope of getting closer to the desired object. (BAUMAN, 1999, p.94).

In my point of view, Bauman's reasoning (idem) can be shifted to the discussion I propose to make about argumentation and authorship. For me, the subject-student is launched to the writing at school space and then, or simultaneously, in the life. To live in these two spheres, the subject must produce texts, some students with more desire, others with less, especially when it comes to written texts. However, not everyone has the right to take the word, to dispute meanings, to feel the pleasure of reading, writing, speaking and being heard. The subjects may want, mainly at school, to argument and to be authors. This is not, however, about the desire; it is about the authority.

The discursive threads that weave this work have been constructed since 2002, when I defended my doctoral thesis. Since then, my researches and supervisions of academic studies have been having argumentation and authorship as main theme. Their results showed how this matter is relevant, since the students that attend high school and even higher education do not demonstrate to argument, or take over authorship of their texts. This situation is very different in the early school years, when the child demonstrates to be seduced, enchanted and moved by discovering the letters, the meanings of the words and the potency to listen and tell stories, and the ability to invent and create new plots, narratives, inventive stories without the fear of "making mistakes". This leads me to question how the methodologies of language teaching practiced in school often discourage and wipe the subject-authors' desire and right to the voice, regarding authorship and argumentation.

\section{About our theoretical basis}

This work is based on the Discourse Analysis constructed by Michel Pêcheux in the late 1960s, in France, and nowadays, especially in Brazil, there are many researchers who are affiliated with this theory. In this discursive perspective, the exteriority is constitutive of the subject and the language; 
according to this theory, language cannot be studied only as a linguistic system in which social and historical do not intervene.

Discourse Analysis considers the production condition of the discourse through the analysis of social, historical and ideological aspects. Thus, the object of study of Discourse Analysis is not the language, or the speech, but the discourse. According to Pêcheux (1993, p. 82), "what works in discursive processes is a series of imaginary formations that designate the place that $A$ and $B$ attribute to themselves and to the other, the image that they make of their own place and the place of the other". This image that the interlocutor makes of himself and the other (that is "who am I for him to speak like that?"; "who is he to speak like that to me?"; "who am I to speak like that to him?"; "who is he for me to speak like that to him?" (PÊCHEUX, 1993, p. 83)) interferes in the production conditions of the discourse, which, according to Pêcheux, are the "circumstances" of a discourse, such as the "place" of the interlocutors, the relation to the historical and social context, which is the existing relation of meaning between the wording and the interdiscourse (what is already said, what is already there), the situation where the discourse appears, and the anticipation mechanisms. In the case of this work, the game of imaginary formations can be pictured from the following worries: what is the image that the school subjects (teachers and students) have about themselves? And that about the writing? And that about interpretation? And that about literary texts? And that about the discursive practice of argumentation? And that about author? Are they (teachers and students) authorized to these discursive practices?

To deal with the game of imaginary formations, it is necessary to deal with the notion of subject, which is not confounded with the subject of Psychology, because it is, according to the discursive theory, a subject effect, of imaginary positions that the individual occupies when producing his discourses. In accordance with Althusser's (1974) thesis, it is the ideology that interpellates the individual in subject. In doing so, the discursive subject may or may not occupy the place of author, copyist or writer; he may or may not argument.

As stated by Orlandi (1993), the enunciator-subject's difficulty to take over the function of author is related to the teaching-learning process, which 
does not manage the author-function with the student, but requires from him this positioning in the text construction. In the authorship, there is an overseen freedom, seeing that the subject, socially represented, experiences a greater charge for what he writes, because he takes over the responsibility for his saying/writing. In Orlandi's words:

We would say that the author is the function that the self takes up as language producer. Because it is the subject's discursive dimension that is more determined by the relation with the exteriority (social and historical context) it is more submitted to the rules of the institutions. The disciplinary procedures are more visible in it (ORLANDI, 1993, p. 77).

The social place that the subject occupies in producing his discourse interferes with the effects of constructed meanings, for example, the exactly same grade achieved in a similar test from different students would generate different effects, as it would be different from the point of view of teachers and students too.

This leads me to question how the methodologies of language teaching, practiced at school, often make it faint and erase the desire and the right to the voice of the subject-authors with regard to authorship and argumentation.

Since 2015, I began to research what I consider the subject's right to argumentation, not focusing on how to argument well, but on how to be able to argument, regardless of whether or not there is a good strategy of persuasion, as I believe that having the right to argument should be the starting point for dealing with questions of argumentation. What interests me is that the subject feels authorized to practice argumentation.

This idea came to me as a result of reading "The Right to Literature", by Antonio Candido, in which the author arguments that access to literature is a human right, as well as the other human rights. According to Candido (2004, p.175), "there may be no social equilibrium without literature." I agree with the author and, from it, I defend (PACíFICO, 2016) that argumentation should also be understood as a human right, a right that must be exercised in the school context, so that the subject-students practice argumentation, inside and outside the school, as a social practice. I emphasize here that I defend the right to the practice of argumentation and not only access to texts that simulate teaching about argumentation, such as those circulating in the school about the production of argumentative-essay texts. 
There is a class struggle in the school context; dominance and resistance constitute the relation between the subjects, then, argumentation may or may not settle. In Portuguese classes, we observe that the student is often afraid to interpret the studied texts, to produce his own text and to show it to the teacher, which is commonly accompanied by the questions such as "Is that right?" and "Teacher, is it what you asked for?". In my point of view, these questions are related to the fact that the student, expected to talk about the referent topic according to the teacher's view, does not see the possibility of assuming, in relation to his own text, the position of subject-author and reader, assumption that implies the responsibility of becoming the author and the ability to argument.

This non-authorization is based on the ideology that works as a mechanism of naturalization of the senses, as if only the authorized subjects (established authors, textbook authors, teachers, scientists) could argument and be authors. In accordance with Althusser (1974), the ideology is vehiculated by mechanisms created by the dominant class in order to confirm and reproduce the material, ideological, and political exploitation conditions. If we consider that we are fated to eternally reproduce the school conditions of uneven (re)production of knowledge, maybe the effort of doing this work would not be worth it. It is Pêcheux who brings us a breach to try to break this way of (re)production of meanings in the school context, by considering the possibility of "transformation of the production relations". According to Pêcheux (1995, p. 133):

Althusser presented the real fundaments of a non-subjectivist theory of the subject, as theory of the ideological conditions of the reproduction/transformation of the production relations, establishing the relation between the unconscious (in the Freudian sense) and ideology (in the Marxist sense).

For considering that, even though it is hard, it is possible to transform the power relations in the relations with the knowledge, in the social relations, in the pedagogical relations, I defend the opposite of silencing pedagogical practices. To that end, the subject must have access to the archive, to the interdiscourse, to the discursive memory, which means that he has to be able to affiliate himself to the regions of meanings in which the discursive object circulates. In order to occupy the place of author, of someone who has the 
right to produce meanings, it is necessary, therefore, that the subject participates and learns (or recognizes) the social and historical process of discourse construction, and that he establishes the relation between archive and interdiscourse, because as Orlandi (2001) states:

Thinking the archive-interdiscourse relation, what matters is to make the subject
notice that there are relations of meanings that transit. There are meanings that
blend, that create filiations. (...) Therefore we aim to modify the image that he
has about the reading, bringing new elements for his reflection, other ways of
reading. Thus, it is about creating conditions so that he works the construction
of documental archives-discourses of every sort - those that open his mind to
different possible meanings, even the unperformed ones (ORLANDI, 2001, p. 71).

The author's state is essential to the discussion I propose, because it highlights the work with the reading in a way that the reader is able to unravel the archive, that is, to read "the relations of meanings that transit" among texts. I assume that the lack of this work - that is, the reading that is not performed through the construction of archives, that silences the social and historical construction of meanings -, marks the beginning of the subject's interdiction to authorship and to argumentation. This relation is better explained in my doctoral thesis (PACÍfICO, 2002), in which I demonstrate that the interpretation (that claims the access to the archive) leads to authorship and that, in order to argument, the subject has to take over the discursive position of author. If there is no interpretation, i.e. if the reading stays in the level of repetition of one meaning, this will bring implications to the subject when producing the text insofar as he will probably repeat the meaning of the text that was read, he will not occupy the discursive position of author, nor will assume an argumentative positioning in relation to the meanings set in discourse.

This leads me to reflect how is the relation of the school-subjects with the archive and how the teacher stands the texts are read and interpreted in the classroom, that is, in what way students have access to a field of documents regarding a certain matter, such as Pêcheux (1997) stands, especially in case we consider that the relation of the man with reading and writing triggers, in postmodernity and because of the new technologies, other processes of (trans)formation: the form of texts, the use of writing that produces multiple writings, the possibilities of authorship and signification affect how the subject relates himself with texts and the world. The school certainly must create 
conditions for the students, through the access to the archive, to read, interpret and produce texts, not as a synonym of homework, but as the weaving of subjects and meanings socially and historically constructed.

To produce his discourses, the subject has to work the interdiscourse in the intradiscourse. This occurs because he identifies himself with a determined discursive formation and this identification, "founder of the (imaginary) unit of the subject, is based on the fact that the elements of the interdiscourse [...] that constitute, in the subject's discourse, the traces of what determines him, are reinserted in the discourse of the very subject" (PÊCHEUX, 1995, p. 163). In order to argument, therefore, we will understand that the subject must have access to the interdiscourse, so that he can identify himself with certain meanings, to enroll himself in one or many discursive formations and, thus perform his right to argumentation. To range the interdiscourse means to be in contact with the meanings already produced on a certain topic, but not simply in contact, it is necessary for the subject to perform gestures of interpretation. In other words, to argument it is first necessary to interpret, to the extent that if there is no interpretation, how can the subject dispute the meanings?

I performed a research (PACÍFICO, 2016) with student-subjects that attended, at the time, elementary school, specifically, third and fourth grades. My goal with this research was to interpret the meanings that these subjects produced about the right to argumentation. As result, I verified that they defend everybody's right to argumentation, as wrote the subject A.L. "Yes, because the argumentation must be in our lives". However, they did not silence that many children are not "taken seriously", that "they can not argument because they are young", that "adults do not take what they say into account". Based on these results, I ask myself: which adults do they refer to? Are teachers included in this statement? What is the situation of the student-subject's right to the argumentation in the school context?

Many papers deal with historical, theoretical and analytical bias in order to understand how argumentative resources are produced and used. I have another purpose, that is, I listen and interpret, in the pecheuxtian meaning, what subject-students have to say, if they feel authorized to the discursive practice of argumentation, if they have the right or not to argumentation. 


\section{Methodology}

Based on this brief contextualization, I will present an analysis made from the reading and discussion, between teacher and students of a Brazilian basic school, from the childhood literature book A History with a thousand monkeys, by the Brazilian writer Ruth Rocha, with the aim of analyzing how the students argument about the book read. The subjects of the research are children from 9 to 11 years old, students of a public school in Ribeirão Preto, Brazil. This book was chosen because of its comic idea and I had as hypothesis of research that it would be easier for the students involved by this comic idea to argument and to assume the authorship in 'their texts.

A history with a thousand monkeys is a narrative that has as main characters the scientist Eduardo Quaresma and Zeca, the telegrapher. On two occasions, the scientist goes to the post office to send telegrams to one of his friends who lives in Transamazonica, asking him to send one or two monkeys to Quaresma to perform experiments. However, due to the telegrapher's spelling mistakes, the monkeys do not stop arriving and the city is invaded by them, which causes situations in which the laughter prevails. This is another reason why I had chosen this book to highlight how the spelling mistakes are considered in the school environment and how it is challenging to argument about them in this institution.

We need to consider that taking the place of the author and the one who arguments in school is not an easy task, especially when the teacher has a writing model and expects all students to look at it as a model. This can be explained by the fact that the author deals with the different, with the unexpected, with the meanings that can come to be and that the authorfunction tries to control in order to construct a well organized text from beginning to end, a movement that does not exist when the student has to fill in the gaps, return to the text read or to answer the questions. In these cases, authorship and argumentation are prohibited.

I understand that the act of interpretation, in the early years, comes from orality and is later materialized in the writing. This means that the idea of alphabetization restricted to exhaustive copies of isolated word is unfruitful and only distances the child from the writing and authorship. Going in another direction, after the process of reading, interpretation and discussion of the 
texts with the student-subjects of this research, the methodological course was the following:

- Discussion about the context in which the book is inserted;

- Analysis of the linguistic elements that provoke laughter, such as puns, word games, irony, paradoxes;

- Access to the archive, to the interdiscourse, so that the meanings were constructed beyond what is considered "literal";

- To finalize, the student-subjects perform a textual production, with the objective of occupying a discursive position of author and argument about the meanings read in Ruth Rocha's book.

The analysis that will be presented was made based on the linguistic materiality of each text, aiming to understand the effect of the interdiscourse in the corpus, the opacity of the language, and the ideology effects. I worked with Ginzburg's (1980) indiciary paradigm, which helped to understand the leads, that is, the linguistic marks of some of the writing cutouts considered more significant to the analysis effects. The meanings can be interpreted through leads and, to investigate them, the indiciary paradigm proposed by Ginzburg (1980) brings important contributions, because the indications no longer have a mystic character as they did in ancient times, and they develop a scientific character, based on theories.

To perform a discursive analysis means to consider the language inscription in history, as well as the production conditions of discourses, in a movement of the corpus analysis with the theory, through which it is possible to reach the acts of interpretation, which are not ready as a model to be followed, but they are constructed in each reading. About this, I consider exemplary what Ferreira (2008) tells us:

Because of the interest of many fields of human sciences in the formidable 'Discourse Analysis method', as if it could dispose of the theory and could circulate autonomously. However, this method is not a 'model' for the comprehension and interpretation of the discourses; it does not exist ready, prefabricated, and does not accept 'orders'. In every analysis procedure, it needs to be constructed, worked, in inseparable partnership with the critical theory, where it is forged (FERREIRA, 1998, p. 17).

I consider Ferreira's quotation very important, especially because it deconstructs the possible illusion of some analyst finding in Discourse Analysis 
"a model" of analysis, a tool that could be applied in the same way in too many corpora. Discourse Analysis is a theoretical and analytical tool in which theory and analysis are inseparable, working in symmetry.

\section{Analyses}

The students of the three grades (first, third and fifth) liked he story very much and manifested this contentment both orally and in writing. This can be related to the fact that it is a story about monkeys and accordingly to Tchernichevski (apud PROPP, 1992, p. 38) "we laugh at animals" and Propp (1992) adds: "The most ridiculous animal is the monkey: more than any other, it reminds of man". Maybe this is the greatest reason that provoked the students to laugh, as well as both argumentation and authorship in the texts the subject-students wrote, as I analyze up next.

The analyses will be presented through clippings, which according to Discourse Analysis should be understood as a part of the discursive functioning of the essays produced by the subjects. The clippings will be presented as they were written, because I consider it crucial to respect the subject-student relationship with the writing produced at the moment of data collection. Cutouts 1, 2 and 3 that you have in your hands are part of a corpus whose meanings about the spelling mistakes of the telegraphist are recurrent. I will read them.

\section{Cutout 1:}

A telegrapher who missed a wrong number, instead of writing 1 or 2 monkeys, the telegrapher forgot the letter " $R$ " from "OR" and many monkeys came. I loved this story because a wrong letter can bring a lot of trouble. (Subject A)

Cutout 2:

It all starts when Dr. Eduardo Quaresma sends a telegram asking for 1 or 2 monkeys, but he does not even notice that the telegrapher wrote it wrong and Quaresma's friend ends up sending 102 monkeys.

By its mistakes in the telegram everything becomes a great confusion, making the story funny.

In my opinion the story is very cool and funny, showing the readers how a simple word modifies the whole sentence. (Subject $B$ )

These meanings about writing wrong constitute the discursive formation that disqualifies, discredits, mocks the mistakes of writing and it circulates continuously in the school context, but not only at schools, it is commonly 
seen in the most varied social spheres. This discursive formation materializes dominant discourse on linguistic uses, about what can and should be allowed in relation to orality, and especially in relation to writing, in such a way that subject-students, even submitted to the school, which controls their writings, which points and highlights their mistakes in the productions.

Cutout 3:

Needless to say, Ruth Rocha's book is good because all books of this writer are great! But this monkey's story is pretty cool. Besides being funny, it shows how a Portuguese mistake in a sentence can be confusing! A scientist orders 1 or 2 monkeys for his studies, but the telegram was written wrong. (Subject C)

It is interesting to observe how the subject sustains his point of view in relation to Ruth Rocha's book, leaving evidence that he knows the author's books and considers them "great" ("they are all great!"). In interpreting the story as "well-heeled," "funny," the subject assumes his point of view about it, an argumentation that contributes to the principle of authorship. According to this production, I wonder: how can there be a dominant discursive formation that supports the discourse that students do not know and do not like to read and write? This student, that wrote the cutout 3 , is a public school student (remembering all prejudices that exist about this Brazilian institution), and he made not only a critical analysis of Ruth Rocha's book that was being analyzed, but also indicated a favorable argumentation over all of the writer's books.

Many textual productions have emphasized the problem of the telegraphist's "confusion" in sending the telegram, as what they consider to be the "wrong writing", elements that have aroused the author's interest in writing about it. Perhaps because the students have experienced what Bagno (2007) calls “orthographic paranoia”. According to Bagno (2007, p. 119), "The traditional attitude of the Portuguese teacher, when receiving a text produced by a student, is to immediately look for the "“mistakes", to direct all their attention to the location and eradication of them."

Although there is an affiliation to this discursive formation that looks for the mistakes, the subject-students construct another argumentative course for their writings, which is possible because the discursive formation itself is bumpy, i.e. it is not homogeneous. In other words, it occurs that the subject who produced the cutout 2 did not criticize the "confusion" provoked by the telegraph writer, as it usually occurs in school when a student does not write 
correctly. Even leaving clues in his text that he knows how the deviations of writing are treated in school, the subject-student inscribes himself in his text and assumes his position in relation to the text read, marking that "in my opinion the story is very cool and funny". That is, he performs gestures of interpretation and authorship that materialize in a writing that argument in the direction of a working language, subject to misunderstandings, which many times may provoke laughter, but not punitive laughter, it is rather a cheerful laugh that leaves the writing lighter, "humorous".

This movement of interpretation, writing and affiliation to a certain region of meaning was possible because the activity was not restricted to a copy of another text, to the rewriting, because if this was the case, the student would not find room to manifest, since the copy has to be faithful to the other's writing. In the case of this work, the student had access to the archive, understood by Pêcheux (1997) as a field of documents about one subject. Then, the research's subject was able to write, to argument and put in discourse formulations that inscribed himself in his writing.

\section{Final considerations}

The cutouts analyzed reinforce my thesis that there is a possibility for the subject to practice argumentation as a right that must be respected and encouraged, so that he does not feel silent about the need to argument, to expose his point of view about the texts and to occupy the author's discursive position. I close this presentation registering my desire to see a school full of authors, of subjects who, when leaving school, authorize themselves to read, write and argument, from teachers who are able to listen to them, from evaluating instances that consider how they produce meaning and make language their home. I desire the right to authorship and argumentation for all who are inside and outside the school space.

\section{References}

BAGNO, Marcos. Preconceito linguístico: o que é, como se faz. 49.ed. São Paulo: Loyola, 2007. 
BAUMAN, Zygmunt. Globalização: as consequências humanas. Tradução: Marcus Penchel. Rio de Janeiro: Jorge Zahar Editor, 1999.

CANDIDO, Antonio. O direito à literatura. In: Vários escritos. São Paulo; Rio de Janeiro: Duas cidades; Ouro sobre Azul, 2004. p. 169-191.

FERREIRA, Maria Cristina Leandro. Nas trilhas do discursivo: a propósito de leitura, sentido e interpretação. In: ORLANDI, E. P. (org.). A leitura e os leitores. Campinas: Pontes, 1998.

PACÍFICO, Soraya Maria Romano. Argumentação e autoria: o silenciamento do dizer. Ribeirão Preto, 2002. 19of. Tese (Doutorado em Psicologia Educacional) - Faculdade de Filosofia, Ciências e Letras de Ribeirão Preto, Universidade de São Paulo, 2002.

. O direito à argumentação no contexto escolar. In: PIRIS, E. L.; FERREIRA, M. O. (org.). Discurso e Argumentação em múltiplos enfoques. Coimbra: Grácio Editor, 2016.

PÊCHEUX, Michel. Por uma análise automática do discurso. In: GADET, F.; HAK, T. (org.). Por uma análise automática do discurso: uma introdução a obra de Michel Pêcheux. Campinas: EdUNICAMP, 1993.

. Semântica e discurso: uma crítica à afirmação do óbvio. Trad. Eni Orlandi et al. Campinas: Ed UNICAMP, 1995.

. Ler o arquivo hoje. In: ORLANDI, E. P. (org.). Gestos de leitura: da história no discurso. Campinas: EdUNICAMP, 1997.

\section{Revisão}

Lucas Pereira da Silva

Mestrando em Letras pela Univesidade de São Paulo

\section{Forma de citação sugerida}

PACÍFICO, Soraya Maria Romano. Language teaching supported by argumentation and authorship. EID\&A - Revista Eletrônica de Estudos Integrados em Discurso e Argumentação, Ilhéus, n. 19, v. 2, p. 154-167, dez.2019. DOI 10.17648/eidea-19-v2-2513. 